\title{
Evaluation of platelet aggregation and platelet derived microparticles in acute leukemia patients
}

\author{
Evaluarea agregării plachetare şi a microparticulelor cu origine \\ trombocitară la pacienţi cu leucemie acută
}

\author{
Andra Costache ${ }^{1 *}$, Silvana Angelescu ${ }^{1,2}$, Doina Barbu ${ }^{2}$, Elena Popescu ${ }^{3}$, \\ Delia Ileana Mut Popescu ${ }^{1}$, Anca Roxana Lupu ${ }^{1,2}$ \\ 1. "Carol Davila" University of Medicine and Pharmacy \\ 2. "Coltea” Clinical Hospital, Hematology Department \\ 3. "Medcenter" Central Laboratory - Center for Excellence in Laboratory Medicine and Pathology
}

\begin{abstract}
Patients with acute leukemia develop abnormalities of haemostasis, leading not only to bleeding, but also to thrombotic complications. The pathogenesis of these complications is complex and multifactorial. Because platelets and platelet derived microparticles are key players in haemostasis and thrombosis, we presumed their roles in the prediction of bleeding and thrombotic complications. Our study groups included 24 patients with acute leukemia and 16 healthy volunteers. Platelet aggregation evaluation was performed by impedance whole blood aggregometry and the ennumeration of platelet derived microparticles was done by means of flow cytometry. Eight patints developed hemorrhagic complications associated with reduced platelet aggregation response at hospital admission. Major thrombotic events occurred in 5 patients, being preceded by increased platelet aggregation in 3 cases and high level of platelet derived microparticles in 2 cases. Our findings reveal that whole blood platelet aggregometry could be a valuable tool especially in the detection of platelet hyperreactivity and in the prediction of thrombotic events. A high level of platelet derived microparticles could also predict thrombosis. These hypotheses need further evaluation and confirmation on larger number of patients.
\end{abstract}

Key words: acute leukemia, platelet aggregation, platelet-derived-microparticles, bleeding, thrombosis

\section{Rezumat}

Pacienţii cu leucemie acută dezvoltă anomalii ale hemostazei care determină apariţia de complicaţii hemoragipare şi chiar trombotice. Patogeneza acestor complicaţii este complexă si multifactorială. Deoarece trombocitele şi microparticulele trombocitare reprezintă elemente cheie în cadrul proceselor de hemostază si tromboză, am încercat să evidențiem rolul lor în predicţia complicaţiilor hemoragice şi trombotice. Grupurile studiate au inclus 24 de pacienţi cu leucemie acută şi 16 voluntari sănătoşi. Evaluarea agregării plachetare s-a realizat prin agregometrie prin impedanţa în sânge integral, iar pentru determinarea microparticulelor trombocitare s-a utilizat citometria în flux. Opt pacienţi au dezvoltat complicaţii hemoragipare, care au fost asociate cu agregabilitate

*Corresponding author: Andra Costache, "Carol Davila" University of Medicine and Pharmacy, Bucharest, România, e-mail: andracostache@gmail.com 
trombocitară diminuată la internare. Evenimentele trombotice majore au complicat evoluţia a 5 pacienţi şi au fost precedate de agregare trombocitară crescută la 3 cazuri şi nivel crescut de microparticule trombocitare la 2 cazuri. Rezultatele noastre evidenţiaza faptul că agregometria plachetară în sânge integral poate fi un instrument valoros in special în identificarea hiperreactivitaţii plachetare şi în predicţia evenimentelor trombotice. Un nivel crescut de microparticule trombocitare poate, de asemenea, să anticipeze apariţia trombozei. Aceste ipoteze necesită evaluare si confirmare pe un număr mai mare de pacienţi.

Cuvinte cheie: leucemie acută, agregare plachetară, microparticule cu origine trombocitară, hemoragie, tromboză

Received: $7^{\text {th }}$ January 2014; Accepted: 17 th April 2014; Published: $5^{\text {th }}$ May 2014.

\section{Introduction}

Acute leukemias (AL) are characterized by uncontrolled clonal proliferation of immature hematopoietic precursors leading to impaired hematopoiesis and its accompanying complications - bleeding, infection and organ infiltration (1). Even though, in terms of haemostasis, the clinical picture is mostly dominated by the bleeding episodes, thrombosis can also complicate the course of the disease (2-6). These complications have a significantly negative impact on the morbidity and mortality and their prediction is often difficult because of the lack of laboratory markers.

Although the pathogenesis of haemostatic defects is complex, a central role is played by the platelets (7), and possibly by the platelet derived microparticles (PMPs) (8). Understanding these defects may contribute to the prediction of these complications as well as to the design of appropriate measures for intervention to prevent them.

Platelets are key players in physiological haemostasis as well as in pathologic bleeding and thrombosis (9). In AL platelets present alterations both in term of number and function. Although thrombocytopenia is the major cause of bleeding, acquired platelet defects have been reported too (10). On the other hand, hyperfunction of platelets is associated with an increased risk of thrombosis and was reported in a number of diseases including cancers (11).

PMPs are vesicles smaller than $1 \mu \mathrm{m}$ released from the surface of activated or apoptotic platelets as a result of membrane remodeling. PMPs are the largest population of circulant microparticles (MPs), representing between 70\% and $90 \%$ of the total number of MPs. PMPs are highly procoagulant due to phosphatidylserine (PS) and tissue factor (TF) expression on their outer membrane, which are the main initiators of the coagulation cascade (12). Elevated levels of PMPs were reported in a wide range of diseases with thrombotic tendency, including cardiovascular diseases and neoplastic diseases (13-18).

In contrast, patients with decreased numbers of PMPs are prone to bleeding diathesis as revealed by Castaman syndrome and Scott syndrome (19).

Our study aimed to evaluate platelet aggregation characteristics by whole blood aggregometry (WBA) and to assess the circulating PMPs levels in patients with AL and their possible role in hemorrhagic and thrombotic complication prediction.

\section{Material and methods}

A number of 24 patients with newly diagnosed AL from the Department of Hematology of Coltea Clinical Hospital, Bucharest and 16 healthy volunteers who had not taken any drugs were recruited for study participation over a 10 months period, between February and November 2012. The patients were diagnosed essentially based on French-American-British (FAB) guidelines by morpho-cytochemical and 
immunophenotypic criteria: 21 of the patients had acute myeloid leukemia (AML) (AML0 - 1 case, AML1 - 1 case, AML2 - 7 cases, AML4 10 cases, AML5 - 1 case, AML6 - 1 case) and 3 acute lymphocytic leukemia (ALL). This study was approved by the Ethics Committee of Coltea Clinical Hospital and written informed consent was obtained from every participant of the study in accordance with the Declaration of Helsinki. All analyses were performed using peripheral venous blood sample collected at the time of diagnosis prior to chemotherapy treatment. The patients were followed-up prospectively for the occurrence of either bleeding or thrombotic manifestation during the first month of hospitalization.

Hematologic parameters were determined with a Sysmex XT 1800i hematology analyzer using ethylene diamine tetraacetic acid (EDTA) sample tubes and plasma coagulation parameters were evaluated with an ACL 9000 (Instrumentation Laboratory) coagulation analyzer from $3.2 \%$ trisodium citrate sample tubes. Coagulation parameters included: prothrombin time (RecombiPlasTin 2G kit, HemosIL), activated partial thromboplastin time (APTT) (APTT-SP kit, HemosIL) and fibrinogen (Fbg) (Fibrinogen-C kit, HemosIL).

Platelet aggregation was assessed in whole blood by multiple electrode aggregometry (MEA) or impedance aggregometry (Multiplate analyzer, Roche). Venous blood was collected by clean venopuncture on hirudin tubes (Hirudin Blood Tube for Multiplate analysis, Roche) after discarding at least first three $\mathrm{mL}$. The final concentration of hirudin was $15 \mu \mathrm{g} / \mathrm{mL}$. The samples were maintained at room temperature avoiding agitation and were analyzed within 3 hours post drawing.

Hirudin-anticoagulated whole blood was diluted 1:1 with physiological saline in single-use test cells and then preheated at $37 \mathrm{C}^{\circ}$ for three minutes. Addition of activating agonist induc- es platelets' activation, adhesion and aggregation on the surface of silver-coated electrodes within each test cell. A Teflon-coated stirring bar rotating at $1000 \mathrm{rpm}$ was used for continual sample mixing. As platelet adhere to the electrode surfaces, the impedance of an alternating current applied across electrodes increases. This change in electrical impedance was recorded continuously for 6 minutes and was expressed by the area under the aggregation curve (AUC) - arbitrary units (AU) plotted against the time (AU*min). Platelets were stimulated by the following agonists: adenosine diphosphate (ADP) (ADPtest, Roche) with a final concentration of $6.5 \mu \mathrm{M}$, collagen (COLtest, Roche) with a final concentration of $3.2 \mu \mathrm{g} / \mathrm{mL}$ and thrombin receptor activating peptide- 6 (TRAPtest, Roche) with a final concentration of $32 \mu \mathrm{M}$.

PMPs enumeration was performed by flow cytometry. Venous blood was drawn into 3.2\% trisodium citrate tubes. Samples were kept at room temperature and processed in an interval of maximum two hours post-drawing. Platelet free plasma (PFP) was obtained by a serial centrifugation protocol $(15 \mathrm{~min}$ at $1500 \mathrm{~g}, 5 \mathrm{~min}$ at $13000 \mathrm{~g}$ ), frozen as $500 \mu \mathrm{L}$ aliquots and stored at $-80 \mathrm{C}$ until use. For PMPs labeling we used monoclonal antibody to CD41 allophycocyanin (APC) -conjugated, clone MEM-06 (Exbio Praha) and Annexin $\mathrm{V}$ fluorescein isothiocyanate (FITC) - conjugated (Annexin V - FITC kit, Beckmann Coulter).

CD41-APC and AnnexinV-FITC pre-diluted in Binding Buffer were added to PFP and incubated for 20 minutes at room temperature, in the dark. Then samples were diluted in Annexin V kit Binding Buffer. Analyses were performed on BD FACSCantoII flow cytometer using FACSDiva software. The setting up of the MP analysis region $(0,5-1 \mu \mathrm{m})$ was done utilizing a blend of calibrated fluorescent beads of three diameters $(0.5,0.9$ and $3 \mu \mathrm{m})$ (Megamix, BioCytex). Single staining controls were used to check fluorescence compensation settings and 
to set up positive regions. PMPs were defined as dual positive $\mathrm{PS}+/ \mathrm{CD} 41+$ events, as seen in dual-color fluorescence plots after staining with Annexin V-FITC and CD41-APC. Counting beads with an established concentration close to 1000 beads $/ \mu \mathrm{L}$ (Flow Count Fluorospheres, Beckman-Coulter) were added to each sample in order to express MP counts as absolute numbers per $\mu \mathrm{L}$ of PFP. The identification of PMP was based on size $(<1 \mu \mathrm{m})$ and the binding of fluorescent-labeled antibodies.

For statistical analysis, data were evaluated with Microsoft Excel 2007 software. Values were expressed as mean +/- SD.

\section{Results}

The main hematologic and coagulation parameters of the 24 patients and 16 controls are displayed in Table I.

The platelet aggregation parameters and PMPs levels of patients and healthy subjects are summarized in Table II.

Of the 24 patients, 8 developed hemorrhagic complication (one patient with AML0, 3 patients with AML2 and 4 patients with AML4. Major thrombotic events (myocardial infarction or stroke) occurred in 5 patients: 2 patients with AML2 and 3 patients with AML4.

Table I. Characteristics of the study groups

\begin{tabular}{lcc}
\hline \multicolumn{1}{c}{ Variables } & Control group & AL Patients \\
\hline $\mathrm{n}$ & 16 & 24 \\
\hline Male / Female & $5 / 11$ & $13 / 11$ \\
\hline Age (years) & $44 \pm 7.9$ & $53.7 \pm 18.4$ \\
\hline Platelets (x 109/L) & $282.94 \pm 18.38$ & $109.46 \pm 128.18$ \\
\hline White Blood Cells $\left(x 10^{9} / \mathrm{L}\right)$ & $6.87 \pm 1.68$ & $26.65 \pm 33.76$ \\
\hline Red Blood Cells $\left(\mathrm{x} 10^{12} / \mathrm{L}\right)$ & $4.59 \pm 0.376$ & $2.5 \pm 0.63$ \\
\hline Hemoglobin $(\mathrm{g} / \mathrm{dL})$ & $13.73 \pm 1.69$ & $8.08 \pm 1.4$ \\
\hline PT $($ sec.) & $10.61 \pm 0.61$ & $13.31 \pm 2.32$ \\
\hline INR & $0.98 \pm 0.056$ & $1.22 \pm 0.21$ \\
\hline APTT (sec.) & $25.95 \pm 2.43$ & $27.42 \pm 5.55$ \\
\hline Fibrinogen $(\mathrm{g} / \mathrm{L})$ & $2.84 \pm 0.51$ & $4.02 \pm 0.99$
\end{tabular}

PT - prothrombin time

APTT - activated partial thromboplastin time

Values are expressed as mean \pm standard deviation.

Table II. Aggregation parameters and PMPs levels of study groups

\begin{tabular}{lccc}
\hline \multicolumn{1}{c}{ Parameters } & Control group & AL Patients & $\begin{array}{c}\text { P values (for Patients } \\
\text { compared to Control) }\end{array}$ \\
\hline ADP aggregation (AUC) & $742 \pm 38.52$ & $293 \pm 83.98$ & $\mathrm{P}=0.000122$ \\
\hline Collagen aggregation (AUC) & $743 \pm 38.23$ & $403 \pm 101.58$ & $\mathrm{P}=0.00983$ \\
\hline TRAP aggregation (AUC) & $1064 \pm 39.30$ & $486 \pm 105.99$ & $\mathrm{P}=0.0000754$ \\
\hline PMPs/ $\boldsymbol{\mu L}$ & $353 \pm 197.70$ & $1302 \pm 821.59$ & $\mathrm{P}=0.239$ \\
\hline AUC - area under aggregation curve & & \multicolumn{2}{c}{ Values are expressed as mean \pm standard deviation. }
\end{tabular}


Our results showed that compared with the control group, patients with AL displayed reduced platelet aggregation response in 19 cases (79\%), increased response in 3 cases $(13 \%)$ and similar response for all agonists in 2 cases $(8 \%)$. The reduced platelet aggregation response was associated with hemorrhagic complications development in 8 patients (42\%) and the increased response to agonists was associated with major thrombotic events (myocardial infarction and stroke) occurrence in all the 3 cases $(100 \%)$.

The three subgroups are too small for a statistical evaluation of the differences.

Figure 1 a,b,c shows a normal aggregation profile in a healthy volunteer.
Figure 2 a,b,c shows impaired aggregation profile in a patient with AL who developed bleeding complications.

Figure 3 a,b,c shows platelet hyperaggregability profile in a patient with AL who developed ischemic stroke.

The level of PMPs was similar to the control group in 21 out of the 24 patients $(88 \%)$ and much higher in 3 patients (12\%), 2 of which developed major thrombotic events $(67 \%)$. These subgroups are too small for a statistical evaluation of the differences, too.

Figure 4 represent a flow cytometric dot plot displaying a high level of PMPs in a patient with AL who developed myocardial infarction in the course of disease.

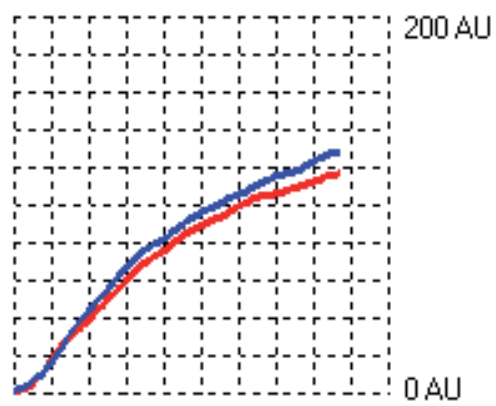

Figure 1a. Normal ADP Aggregation Curve (impedance aggregometry) in a healthy volunteer. $\mathrm{AUC}=682 \mathrm{AU} * \min$

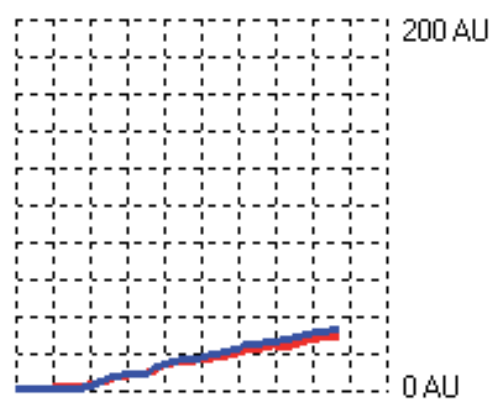

Figure 2a. Impaired ADP Aggregation Curve (impedance aggregometry) in a patient with AL. AUC $=126$ AU*min

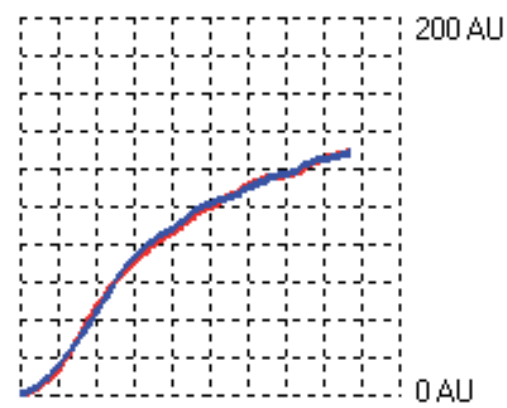

Figure 1b. Normal Collagen Aggregation Curve (impedance aggregometry) in a healthy volunteer. $\mathrm{AUC}=\mathbf{7 3 2} \mathrm{AU}$ * min

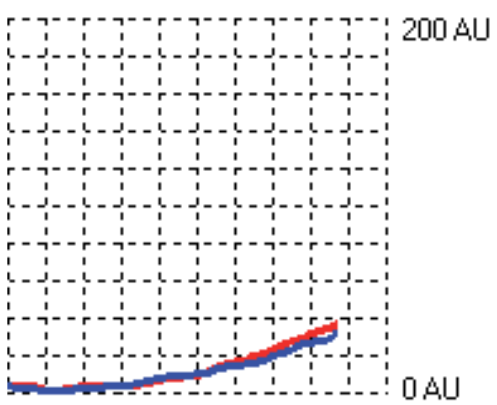

Figure 2b. Impaired Collagen Aggregation Curve (impedance aggregometry) in a patient with AL. AUC $=95 \mathrm{AU}^{*}$ min

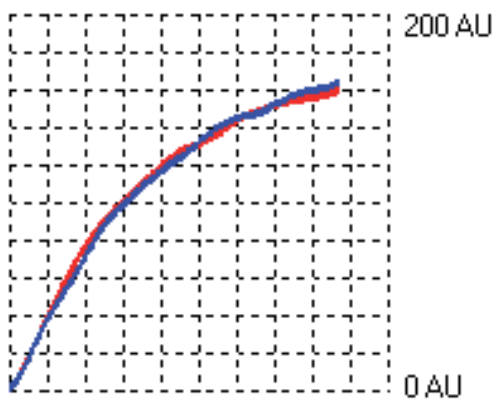

Figure 1c. Normal TRAP Aggregation Curve (impedance aggregometry) in a healthy volunteer. $\mathrm{AUC}=1000 \mathrm{AU}^{*} \mathrm{~min}$

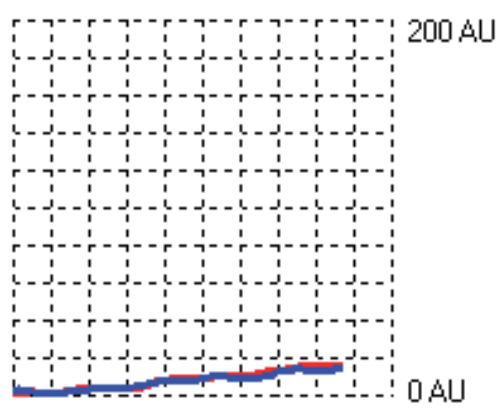

Figure 2c. Impaired TRAP Aggregation Curve (impedance aggregometry) in a patient with AL. AUC $=61 \mathrm{AU}^{*}$ min 


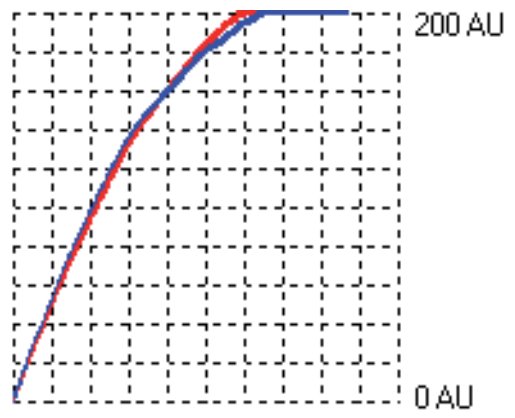

Figure 3a. ADP Aggregation

Curve (impedance aggregometry) displaying platelet hyperreactivity in a patient with AL. AUC $=1374$ AU*min

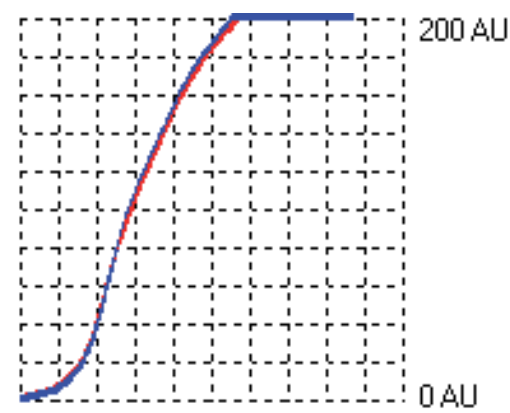

Figure 3b. Collagen Aggregation Curve (impedance aggregometry) displaying platelet hyperreactivity in a patient with AL. AUC $=1295$ AU*min

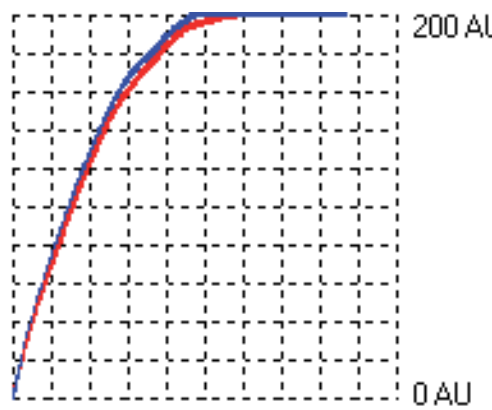

Figure 3c. TRAP Aggregation Curve (impedance aggregometry) displaying platelet hyperreactivity in a patient with AL. AUC $=1496$ AU * min

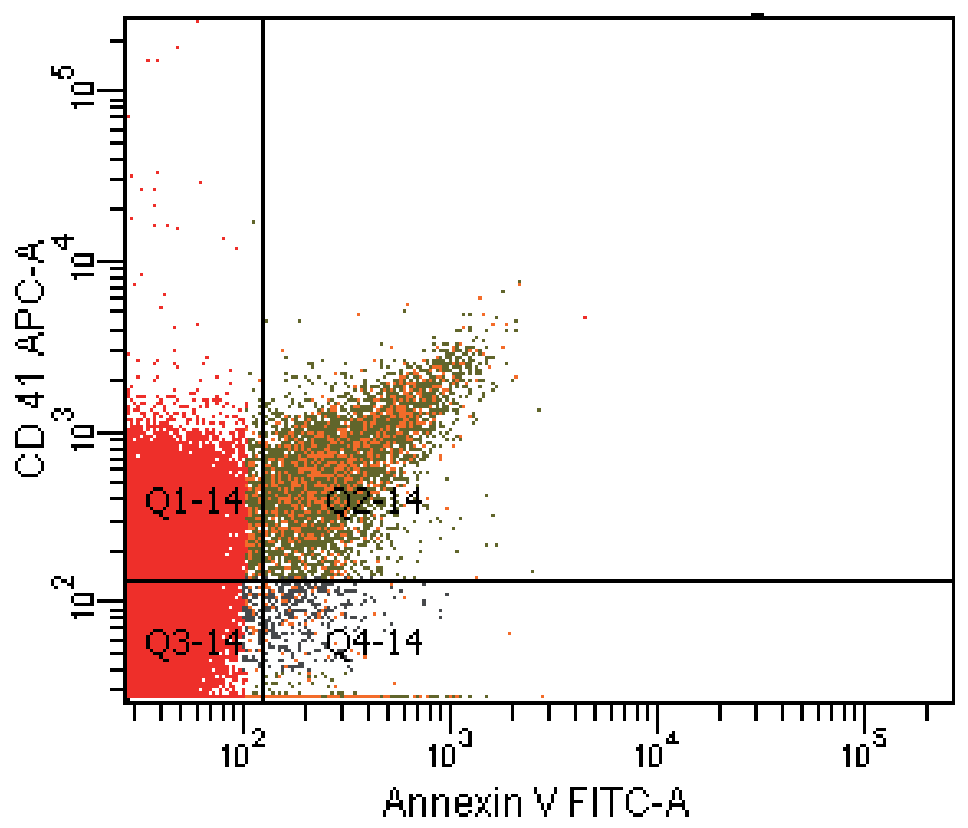

Figure 4. Flow cytometry dot plot displaying a high level of PMPs. PMPs are dual positive PS+/CD41+ events, stained with Annexin V-FITC and CD41-APC.

\section{Discussion}

A number of factors that prone to bleeding have been reported in patients with AL: thrombocytopenia, endothelial cell injury, disseminated intravascular coagulation, excessive fibrinolysis, acquired hemophilia, acquired von
Willebrand syndrome, drugs (e.g., antiplatelet drugs and anticoagulant therapy and associated comorbidities (e.g., infections, impaired liver function, impaired kidney function, malnutrition) (20). However, the primary determinant of the bleeding risk in these patients is the degree 
of thrombocytopenia (21). The relationship between bleeding and the platelet count has been well documented in the literature, major hemorrhage being more likely at thrombocytopenia below $10000 / \mu 1$ (22). Notwithstanding, bleeding may happen in some patients with higher platelet counts and numerous other patients with even severe thrombocytopenia do not experience spontaneous hemorrhage. Therefore, platelet count alone is not suitable in bleeding occurrence prediction, platelet function being also significant (23). In our study group, bleeding occurred in patients with platelet counts between 12000 and $33000 / \mu 1$. As expected, in these patients, platelet aggregation curve was collapsed and in two of them aggregation was absent. However platelet aggregation assay cannot discriminate between the effects of impaired platelet function and the effects of thrombocytopenia. WBA results cumulate the interactions between thrombocytes, leukocytes, and erythrocytes to reproduce the complex in vivo setting (24).

In our study PMPs levels seem to have no clinical relevance in acute leukemia patients with bleeding complications.

The pathogenesis of the prothrombotic state in AL patients is complex, involving the interplay of multiple factors: hyperleukocytosis, increased expression of molecules of adhesion by endothelial cells and the homologous receptors in blast cells, increased expression of TF, cancer procoagulant presence, cell derived microparticle expressing PS and TF, adverse effects of therapeutic agents, vascular access catheters, comorbid conditions (e.g., thrombophilia, infections) $(20,25-27)$. Although studies report the platelet hyperreactivity as a risk factor for thrombosis in solid neoplasms (11), scarce data are available concerning platelet role in thrombotic complications occurrence during the course of leukemic disease. Our findings suggest that platelet hyperreactivity may play a crucial role in major thrombotic events onset in patients with $\mathrm{AL}$, however further studies are needed to confirm this hypothesis and to prove its impact in predicting and preventing these complications.

Circulating PMPs are important procoagulant factors $(14,18)$ and the hypercoagulable state in patients developing thrombotic events could be partially explained by the elevated levels of PMPs.

However, a limitation of this study is the small number of patients enrolled.

\section{Conclusions}

Our study confirms that the low platelet count remains the main predictor of hemorrhagic complications. Platelet hypoaggregability could also precede bleeding complications, while platelet hyperreactivity could predict major thrombotic events in leukemic patients. To our knowledge, this is the first study pointing out platelet hyperreactivity in AL patients.

Our data suggests that PMPs enumeration could offer significant information on the haemostatic status of patients with AL, increased levels of PMPs suggesting a procoagulant status and an increased risk of thrombotic events.

Notwithstanding our study group was too small, this hypothesis requiring further evaluation and validation.

\section{Acknowledgments}

This study was supported by "Coltea" Clinical Hospital - Bucharest.

\section{Disclosure}

The authors state that they have no conflict of interest.

\section{Abbreviations}

ADP - adenosine diphosphate

AL - acute leukemia

ALL - acute lymphocytic leukemia 
AML - acute myeloid leukemia

APC - allophycocyanin

APTT - activated partial thromboplastin time

AU - arbitrary units

AUC - area under the aggregation curve

Fbg - fibrinogen

FITC - fluorescein isothiocyanate

MEA - multiple electrode aggregometry

MPs - microparticles

PFP - platelet free plasma

PMPs - platelet derived microparticles

PS - phosphatidylserine

TF - tissue factor

TRAP - thrombin receptor activating peptide- 6

WBA - whole blood aggregometry

\section{Bibliography}

1. Rassi F El, Arellano M. Update on optimal management of acute myeloid leukemia. Clin Med Insights Oncol. 2013 Aug 12;7:181-97. DOI: 10.4137/CMO.S8528

2. Mohren M, Markmann I, Jentsch-Ullrich K, Koenigsmann M, Lutze G, Franke A. Increased risk of venous thromboembolism in patients with acute leukaemia. $\mathrm{Br}$ J Cancer. 2006 January 30;94(2):200-2. DOI: 10.1038/ sj.bjc. 6602945

3. De Stefano V, Sora F, Rossi E, Chiusolo P, Laurenti L, Fianchi L, et al. The risk of thrombosis in patients with acute leukemia: occurrence of thrombosis at diagnosis and during treatment. J Thromb Haemost. 2005 Sep;3(9):1985-92. DOI: 10.1111/j.15387836.2005.01467.x

4. Falanga A, Marchetti M, Russo L. Venous thromboembolism in the hematologic malignancies. Curr Opin Oncol. 2012 Nov;24(6):702-10. DOI: 10.1097/ CCO.0b013e3283592331

5. Franchini M, Frattini F, Crestani S, Bonfanti C. Bleeding complications in patients with hematologic malignancies. Semin Thromb Hemost. 2013 Feb;39(1):94100. DOI: $10.1055 / \mathrm{s}-0032-1331154$

6. $\mathrm{Ku} \mathrm{GH}$, White RH, Chew HK, Harvey DJ, Zhou H, Wun T. Venous thromboembolism in patients with acute leukemia: incidence, risk factors, and effect on survival. Blood. 2009 113(17):3911-17. DOI: 10.1182/ blood-2008-08-175745

7. Qian X, Wen-Jun L. Platelet Changes in Acute Leukemia. Cell Biochem Biophys. 2013 Dec;67(3):1473-9. DOI: $10.1007 / \mathrm{s} 12013-013-9648-\mathrm{y}$

8. Stein E, McMahon B, Kwaan H, Altman JK, Frankfurt O, Tallman MS. The coagulopathy of acute promyelocytic leukaemia revisited. Best Pract Res Clin
Haematol. 2009 Mar;22(1):153-63. DOI: 10.1016/j. beha.2008.12.007

9. Jennings LK. Mechanisms of platelet activation: need for new strategies to protect against platelet-mediated atherothrombosis. Thromb Haemost. 2009 Aug;102(2):248-57. DOI: 10.1160/TH09-03-0192

10. Foss B, Bruserud O. Platelet functions and clinical effects in acute myelogenous leukemia. Thromb Haemost. 2008 Jan;99(1):27-37. DOI: 10.1160/TH07-040240

11. Cooke NM, Egan K, McFadden S, Grogan L, Breathnach OS, O'Leary J, et al. Increased platelet reactivity in patients with late-stage metastatic cancer. Cancer Med. 2013 August;2(4):564-70. DOI: 10.1002/ cam4.86

12. Costache A, Avram SI, Cernucan A, Barbu D, Angelescu S, Mut Popescu D, et al. What about microparticles? Perspectives and practical aspects. Rev Romana Med Lab. 2013;21(1):9-15. DOI: 10.2478/rrlm-2013-0013

13. Auwerda JJ, Yuana Y, Osanto S, de Maat MP, Sonneveld P, Bertina RM, et al. Microparticle-associated tissue factor activity and venous thrombosis in multiple myeloma. Thromb Haemost. 2011 Jan;105(1):14-20. DOI: 10.1160/TH10-03-0187

14. Lacroix R, Dubois C, Leroyer AS, Sabatier F, Dignat-George F. Revisited role of microparticles in arterial and venous thrombosis. J Thromb Haemost. 2013 Jun;11(Suppl 1):24-35. DOI: 10.1111/jth.12268

15. Bucciarelli P, Martinelli I, Artoni A, Passamonti SM, Previtali E, Merati G et al. Circulating microparticles and risk of venous thromboembolism. Thromb Res. 2012 May;129(5):591-7. DOI: 10.1016/j.thromres.2011.08.020

16. Campello E, Spiezia L, Radu CM, Bulato C, Castelli M, Gavasso S et al. Endothelial, platelet, and tissue factor-bearing microparticles in cancer patients with and without venous thromboembolism. Thromb Res. 2011 May;127(5):473-7. DOI: 10.1016/j.thromres.2011.01.002

17. Duchemin J, Ugo V, Ianotto JC, Lecucq L, Mercier B, Abgrall JF. Increased circulating procoagulant activity and thrombin generation in patients with myeloproliferative neoplasms. Thromb Res. 2010 Sep;126(3):23842. DOI: 10.1016/j.thromres.2010.06.025

18. Tan X, Shi J, Fu Y, Gao C, Yang X, Li J et al. Role of erythrocytes and platelets in the hypercoagulable status in polycythemia vera through phosphatidylserine exposure and microparticle generation. Thromb Haemst. 2013 Jun;109(6):1025-32. DOI: 10.1160/TH12-110811

19. Siljander PR. Platelet-derived microparticles - an updated perspective. Thromb Res. 2011 Jan;127(Suppl 2):S30-3. DOI: 10.1016/S0049-3848(10)70152-3

20. Kwaan HC. Double hazard of thrombophilia and bleeding in leukemia. Hematology Am Soc Hematol 
Educ Program. 2007:151-7. DOI: 10.1182/asheducation-2007.1.151

21. Webert K, Cook RJ, Sigouin CS, Rebulla P, Heddle NM. The risk of bleeding in thrombocytopenic patients with acute myeloid leukemia. Haematologica. 2006 Nov;91(11):1530-7.

22. Slichter SJ. Relationship between platelet count and bleeding risk in thrombocytopenic patients. Transfus Med Rev. 2004 Jul;18(3):153-67. DOI: 10.1016/j. tmrv.2004.03.003

23. Psaila B, Bussel JB, Frelinger AL, Michelson AD. Differences in platelet function in patients with acute myeloid leukemia and myelodysplasia compared to equally thrombocytopenic patients with immune thrombocytopenia. J Thromb Haemost. 2011 Nov;9(11):2302-10. DOI: $10.1111 / \mathrm{j} .1538-7836.2011 .04506 . \mathrm{x}$

24. Robier C, Neubauer M, Sternad H, Quehenberger F,
Rainer F, Neumeister P. Evaluation of platelet function and pharmacological platelet inhibition in patients with myeloproliferative disorders using multiple electrode aggregometry. Thromb Res. 2010 Sep;126(3):232-7. DOI: 10.1016/j.thromres.2010.06.014

25. Falanga A, Rickles FR. Management of thrombohemorrhagic syndromes (THS) in hematologic malignancies. Hematology Am Soc Hematol Educ Program. 2007:165-71. DOI: 10.1182/asheducation-2007.1.165

26. Nadir Y, Katz T, Sarig G, Hoffman R, Oliven A, Rowe $\mathrm{JM}$, et al. Hemostatic balance on the surface of leukemic cells: the role of tissue factor and urokinase plasminogen activator receptor. Haematologica. 2005 Nov;90(11):1549-56.

27. Crespo-Solis E. Thrombosis and acute leukemia. Hematology. 2012 Apr;17(Suppl 1):S169-73. DOI: 10.117 9/102453312X13336169156852 